\title{
A CURRENT PROBLEM FOR STEEL BRIDGES: FATIGUE ASSESSMENT OF SEAMS REPAIR
}

\author{
TEKUĆI PROBLEMI ČELIČNIH MOSTOVA: PROCENA ZAMORA SANIRANIH \\ ŠAVOVA
}

\section{H. PASTERNAK \\ A. CHWASTEK}

\section{INTRODUCTION}

In dynamically loaded components, weld transitions are often the reasons for cracking with subsequent crack growth. In many cases they restrict the life of the components and structures. There are also deviations that could not be taken into account in the design of the construction, for example, larger loads and the desire for prolonged use.

To the best of the authors knowledge no design concept for the load capacity of the weld after the repair is known to this day. In a research project [Nitschke 2015, Pasternak 2015], in which not only the Department of Steel Construction of the BTU but also the Institute of Joining and Welding Technology at the TU Braunschweig (both Germany) and the Institute of Engineering and Materials Science of the University Innsbruck Austria took part, FAT classes for renovated welds are developed for the first time.

\section{RESEARCH SCHEDULE}

Since fillet welds contain significant higher stress concentration than in butt ones, in the following paper the experimental investigations were carried out indeed using specimens with fillet welds under tensile stresses. The fatigue strength of whole structure decisively depends on details, which are mostly welded joints. Weld transitions are the most critical locations where fatigue cracks are more likely to occur and later grow. Quite often it comes to fatigue failure even at non-load carrying details e.g. transverse attachment of a bridge

H. Pasternak, Brandenburg University of Technology, Cottbus, Germany

A. Chwastek, Brandenburg University of Technology,

Cottbus, Germany
ORIGINALNI NAUČNI RAD

ORIGINAL SCIENTIFIC PAPER

UDK:624.21.014.2

doi:10.5937/GRMK2002003P

girder. It was a reason for the choice of specimens in this research. The examined specimen in this paper are transverse non-load carrying attachment with fillet welds manufactured from steel grade S355J2N (Figure 1).
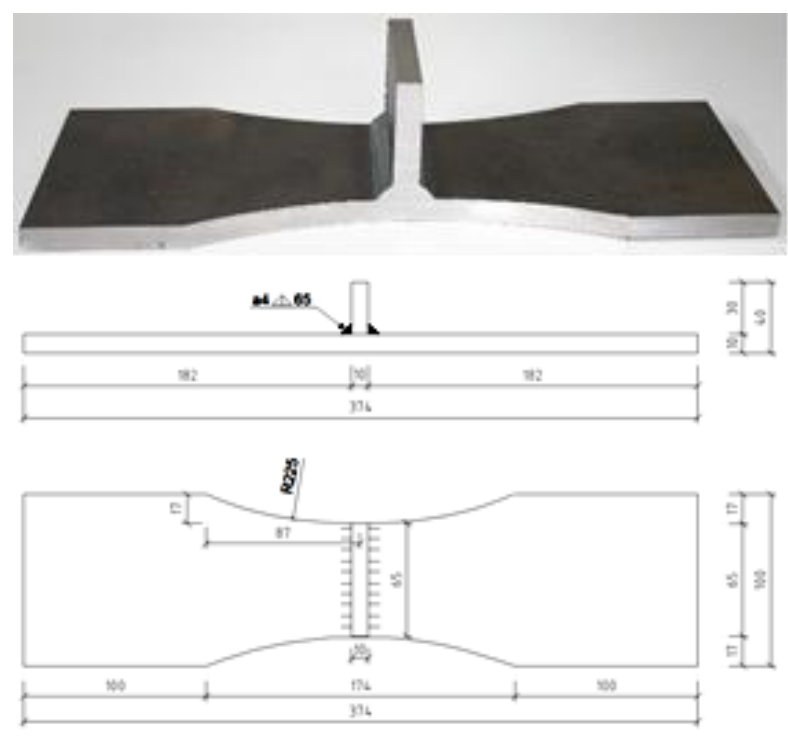

Figure 1. Geometry of specimen

For such geometry of specimen, a fatigue crack is expected to occur at weld toe and is mostly caused by concentration of notch stresses (Figure 2). To make possible a comparison the results of fatigue strength for the welds after seams repair and additionally seams' reworking methods the fatigue strength test analyses were divided into three groups.

- Group I: fatigue strength tests for defect-free weld seams; 
- Group II: fatigue strength tests for seams' repair scenario, i.e. flawed weld seams renovated by grinding the existed crack and re-welding;

- Group III: fatigue strength tests for analogous to group II but supplemented by post-weld treatment methods.

The test schedule is given in Table 1 , whereas the Table 2 shows parameter of welding.

Table 1. Investigation schedule

\begin{tabular}{|l|l|}
\hline \multicolumn{2}{|c|}{ Test schedule - seams repair with the existed crack } \\
\multicolumn{1}{|c|}{ (prior damage) }
\end{tabular}

Table 2. Welding parameters of specimens during manufacturing

\begin{tabular}{|c|c|c|c|}
\hline I [ampere] & 320 & $\begin{array}{c}\text { process of } \\
\text { welding }\end{array}$ & 135 \\
\hline$U$ [volt] & 30,8 & $\begin{array}{c}\text { position of } \\
\text { welding }\end{array}$ & PB \\
\hline $\begin{array}{c}\text { Vs -welding speed } \\
\text { [cm/min] }\end{array}$ & 40 & $\begin{array}{c}\text { wire } \\
\text { electrode }\end{array}$ & G4Si1 \\
\hline $\begin{array}{c}\text { VD - wire feed } \\
\text { speed [m/min] }\end{array}$ & 11 & - & - \\
\hline
\end{tabular}

\section{MANUFACTURING OF TEST SPECIMENS}

\subsection{Original State}

The original state is given on Figure 1 and Table 2.

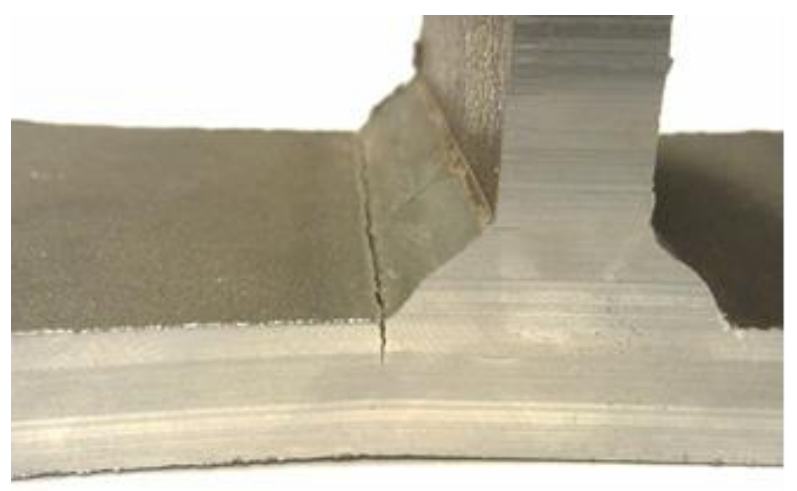

Figure 2. Crack at weld toe

\subsection{Seams 'repair}

In repair state the potentially existing cracks were removed by grinding of weld toe area. It was proceeded using a milling machine. In order to get an adequate fusion in the HAZ the excavated groove of the flawed material was performed in V-shape (Figure 3). A stage of re-welding was carried out using arc welding and supplemented in 3 welding layers (Figure 4). These weld seams characterize much flatter shape in comparison to the ones in original state.

\subsection{Seams re-working method}

In order to explore the effects of mechanically treated weld toes on the fatigue strength the high frequency hammer treatment with frequency of $230 \mathrm{~Hz}$ was applied.

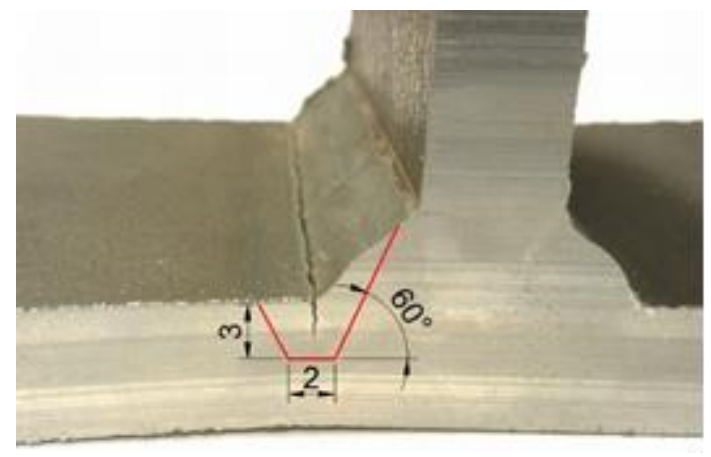

Figure 3. Grinding of crack

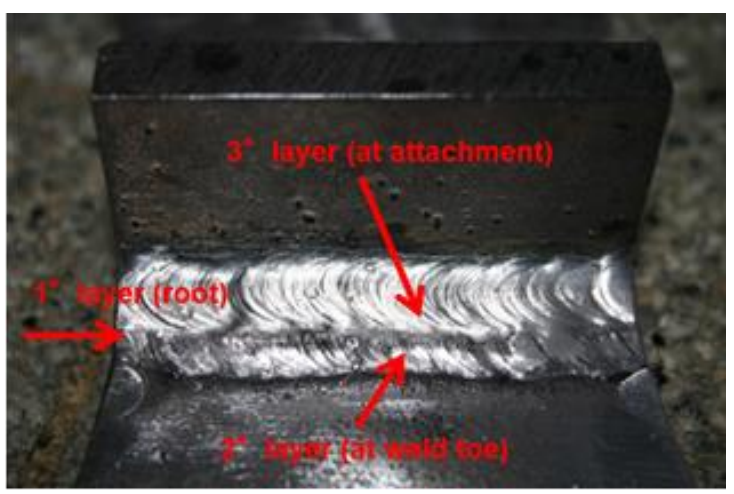

Figure 4. Repair welding layers

\section{EXPERIMENTAL INVESTIGATION AND RESULTS}

The fatigue tests were carried out with frequency of loading $30 \mathrm{~Hz}$ using a servo hydraulic fatigue test machine (Figure 5). According to recommendation for fatigue tests the specimens were loaded in five different load levels. To determine a Wöhler curve just specimens with the crack at weld toe were taken into consideration. The run-out samples were indicated on diagrams by data points with arrow marks. The fatigue loading was alternating axial tensile with assumption of stress radio $R$ $=0,1$ and fixed slope of Wöhler curve $\mathrm{m}=-3$.

The following numbers of specimens were investigated: 29 for group I (original state), 13 for group 
II (after seams repair) as well as 13 for group III (with post-weld treatment). The data points were presented in Wöhler diagram (Figure 6). For the group I the fatigue strength has a value of $104 \mathrm{~N} / \mathrm{mm}^{2}$, for the group II $124,5 \mathrm{~N} / \mathrm{mm}^{2}$ and accordingly for group III $116,5 \mathrm{~N} / \mathrm{mm}^{2}$. It concerns a probability of survival of $50 \%$, i.e. regression line. The results show that the weld seams after repairing process could easily achieve the fatigue strength of those in initial state. In some cases, is being observed even the considerable enhancement of fatigue life. But it should be mentioned that such repair procedures can lead to the increase of misalignments of specimen geometry. The post weld treatment i.e. the high frequency hammer delivered in this case negligible effects on the fatigue strength to compare with the original ones.

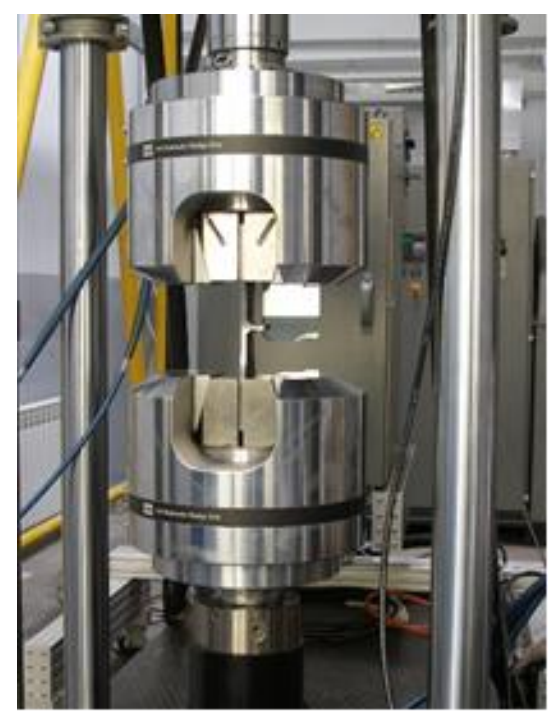

Figure 5. Hydraulic fatigue test machine

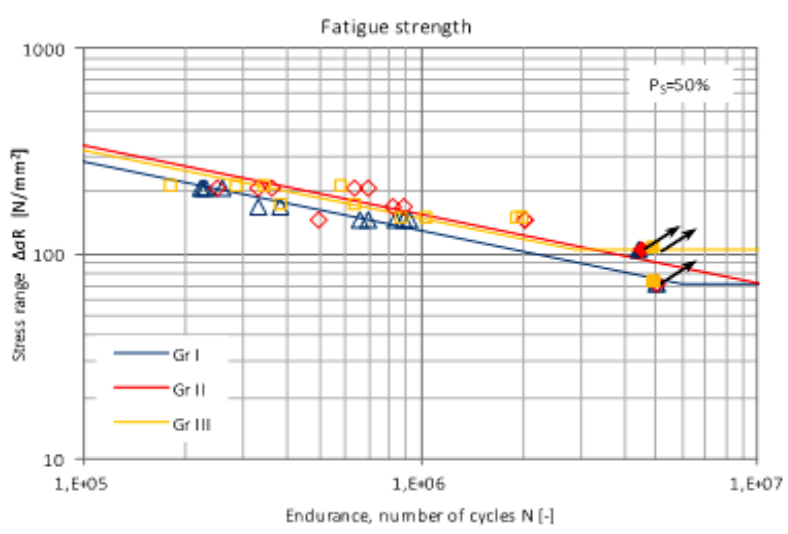

Figure 6. Comparison of results from three states

\section{NUMERICAL INVESTIGATION}

\subsection{Welding simulation}

The welding simulation should be carried out as realistically as possible. In order to realize this, the structure transformation of material, material properties as well as temperature dependence of the material were taken into account in analyses. The residual stresses of the specimens were calculated using the software package SYSWELD [Nitschke 2015]. For this simulation matter especially thermo-mechanical coupling in the material and the geometric preparation of the seam itself. Therefore, the temperature field and macrosection were experimentally measured. It was necessary to calibrate accordingly the moving heat source of the welding simulation. To meet the test conditions as closely as possible, these analyses considered in advance simulation of welding the transverse attachment to the base plate (Figure 7, left) and afterwards cutting out every sample separately (Figure 7 , right).

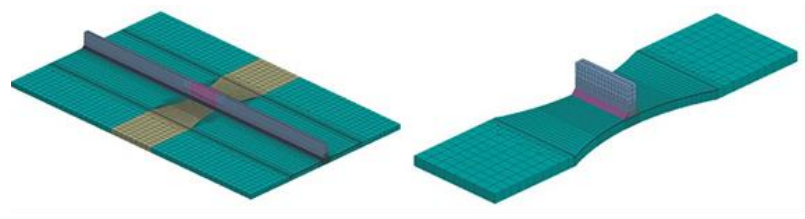

Figure 7. Base plate with transverse attachment (left) and separate specimen (right) [Nitschke 2015]

The modelling of the repair process was also quite realistic. A flawed part of fillet weld and material was "numerically" removed and re-welded (Figure 8).
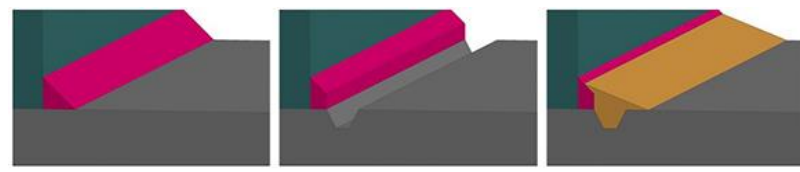

Figure 8. Schematic drawing of seams repair. Fillet weld (left), milled part (center) repaired seam (right)

\subsection{Fatigue strength assessment concepts}

Beside a purely experimental determination the fatigue resistance can be verified according to three analytical concepts. They are based on nominal, structural and notch stresses. Particular attention is paid to local approaches (i.e. structural and notch stress approach) since they are recommended due to better efficiency for welded joints [Hobbacher 2008, Morgenstern 2006].

The nominal stress approach concerns stresses calculated in the sectional area of potential crack initiation region using simple beam theory. The local stress concentrations of the welded joints are disregarded. The fatigue verification occurs in form of relation of stress ranges towards FAT classes, which generally were delivered from fatigue tests. The local stress peak is covered on the resistance side.

The structural stresses include both nominal stresses and the effects of structural discontinuities due to structural detail of welded joint, but excluding the notch effects of the weld profile itself. These fictive stresses are calculated through extrapolation to the weld toe stresses from two or three reference points taken from certain distances from the weld toe.

The basics of the notch stress concept relate to the principle of Neuber at location of potential crack initiation (either at the weld toe or the root). This concerns a 
theory of macro- and micro-support, with basic assumption that the full notch stress at the weld toe affects fatigue failure. According to this approach all edges at weld toe were rounded with the fictitious radius $r_{t}=1 \mathrm{~mm}$ and for such geometry the effective notch stresses were calculated. A master S-N curve for this concept has a value of FAT 225. The FE calculations are required to determine the effective notch stress.

\subsection{FAT classes according to structure and notch stress concept}

The structure stress was determined using 20-nodes volume elements of type C3D20R. Table 3 contains various models with calculated stress concentration factors. The value of this factor for original state was $\mathrm{k}_{\mathrm{t}}=$ 1,15 and after seams repair $\mathrm{k}_{\mathrm{t}}=1,21$ [Chwastek 2019].

The notch stress for original state was analysed both with shell and solid elements. The 8-nodes elements of type S8R were used for the shell model and the same elements like in the structural stress concept for the volume model. Table 4 shows a comparison of the calculated stress concentration factors for the original state. The values of this factor are a little higher by model using volume elements. For this reason, just volume model was analysed in the case of seams repair. The value of stress concentration factor for original state was $K_{t}=2,3$ and after seams repair $K_{t}=2,2$ [Chwastek 2019]. The lower value by repaired welds results from considerably flatter seams shape after repairing.

Table 3. Comparison of the FE calculations of structural stress

\begin{tabular}{|c|c|c|}
\hline model & Volume elements C3D20R & $\begin{array}{c}\text { Calculated } \\
\mathrm{k}_{\mathrm{t}}\end{array}$ \\
\hline $\begin{array}{c}\text { Original } \\
\text { state } \\
\text { (group I) }\end{array}$ & & $\mathbf{k}_{\mathbf{t}}=\mathbf{1 , 1 5}$ \\
\hline $\begin{array}{c}\text { Seams } \\
\text { repair } \\
\text { (group II) }\end{array}$ & & $\mathbf{k}$ \\
\hline
\end{tabular}

Figure 9 shows determined FAT classes for three assessment concepts. For each approach the value of calculated FAT notch detail is considerably higher than in the currently valid standards [DIN EN 1993-1-9 2010] or guidelines [Hobbacher 2008]. Additionally, the results confirm a conservatism of notch class according to EC3 [DIN EN 1993-1-9 2010] for detail of transverse attachment with fillet welds. This applies in particular to nominal and structural stress concept, whereby value of improvement reach even till $20 \%$.
Table 4. FE calculation of notch stress for seams repair

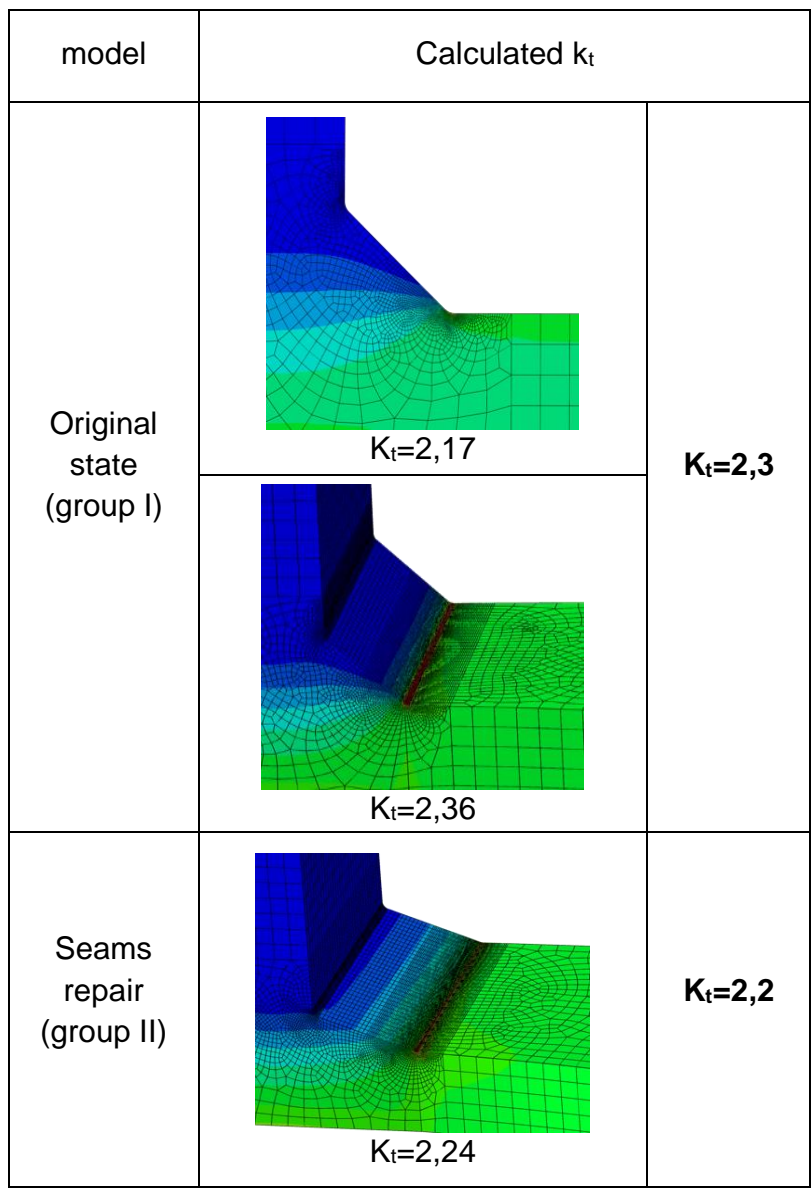

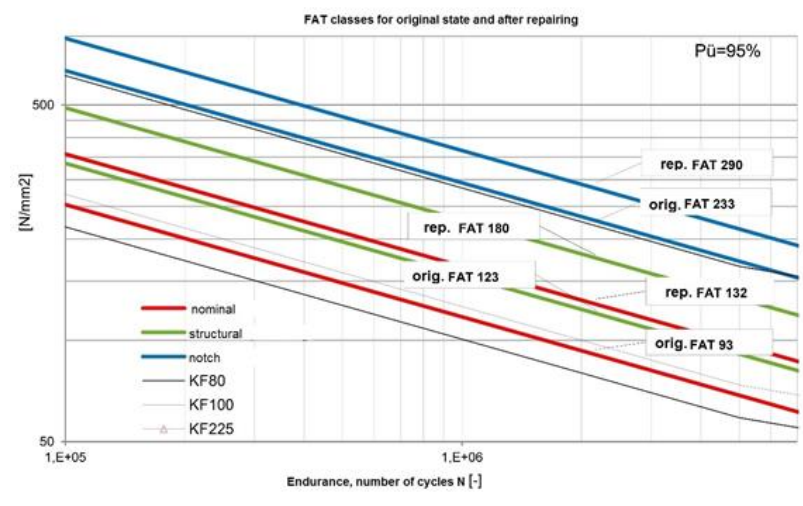

Figure 9. FAT categories of original state and after seams repair

\section{CONCLUSIONS}

As it was shown in experimental and numerical investigations of steel plates with welded transverse attachment, these repair procedures can lead to considerable improvement of fatigue strength in comparison to original state. In this case, using the post treatment methods with the high frequency hammer is rather no advisable. 
The following procedure of cracks repairing by steel bridges is recommended: At first the flawed part of weld seam and material should be removed. It was assumed that grinding reaches till maximal $30 \%$ of plate thickness. The prepared form is afterwards re-welded using arc welding method. Since the excavated groove is relatively large, it is recommended to use the 3-layers welding. In that case such repaired weld seam fails to match the dimensions of seam from original state.

The following conditions must be noticed: stress ratio $\mathrm{R}=0,1$, assumption of imperfection according to IIWRecommendations; T-joints detail geometry; steel grade S355, seam thickness $5 \mathrm{~mm}$ and plate thickness $10 \mathrm{~mm}$.

\section{ACKNOWLEDGMENT}

The authors would like to thank the German Federation of Industrial Research Associations (AiF) for its financial support on the research project IGF-no. 54 EBG. This project was carried out under the auspices of $\mathrm{AiF}$ and financed within the budget of the Federal Ministry of Economics and Technology (BMWi) as part of the program to support Industrial Community Research and Development (IGF).

\section{REFERENCES}

[1] Nitschke-Pagel T., Pasternak H., Lener G. et al.: Bemessungskonzepte für Trag- und Dauerfestigkeitsberechnungen von Reparaturschweißungen- Repair Welding of Structures, Research Project IGF-No. 54EBG, 2015

[2] Pasternak H., Chwastek A.: Zur Entwicklung eines Bemessungskonzeptes für die Lebensdauer von Reparaturschweißungen. Bauingenieur Vol. 90(2015) pp.47-54 and pp. 272-277

[3] Hobbacher A.: Recommendations for fatigue design of welded joints and components. Doc.IIW XIII-1539-96/XV845-96, Paris, October 2008

[4] Morgenstern C. et al.: Fatigue design of aluminium welded joints by the local stress concept with fictitious notch radius of $\mathrm{r}_{\mathrm{t}}=1 \mathrm{~mm}$. International Journal of Fatigue Vol. 28(2006), pp.881-890

[5] Chwastek A.: Beitrag zur Entwicklung von Bemessungskonzepte für Dauerfestigkeitsberechnungen von Reparaturschweißungen, basierend auf kleinen Musterbauteilen, Dissertation, BTU, Cottbus. Germany 2019

[6] DIN EN1993-1-9:2010, Eurocode 3: Bemessung und Konstruktion von Stahlbauten -Teil 1-9: Ermüdung, Dezember 2010

\section{ABSTRACT}

\section{A CURRENT PROBLEM FOR STEEL BRIDGES: FATIGUE ASSESSMENT OF SEAMS REPAIR}

\section{H. PASTERNAK \\ A. CHWASTEK}

The paper describes the results from a research project about repair of welds. The repair was carried out by grinding the flawed seams and re-welding them. The main task was to determine the FAT classes of original state and after repair of seams according to the assessment procedures, such as nominal, structural and effective notch stress approach. The first part shows the results of the tests, the second part encloses numerical analysis and evaluation of results to determine the fatigue strength classes according to three assessment procedures.

Key words: Steel bridges, repair of welds, fatigue stress, fatigue assessment

\section{APSTRAKT}

\section{TEKUĆI PROBLEMI ČELIČNIH MOSTOVA: PROCENA ZAMORA SANIRANIH ŠAVOVA}

\section{H. PASTERNAK \\ A. CHWASTEK}

$U$ radu su predstavljeni rezultati naučnog projekta koji se bavi ispitivanjem saniranih šavova zavarenih spojeva. Postupak sanacije se sastojao od mehaničkog uklanjanja oštećenog šava i ponovnog zavarivanja. Glavni zadatak projekta je bio određivanje klase otpornosti na zamor u prvobitnom stanju i nakon sanacije šavova, primenom pristupa nominalnog, efektivnog i "hot-spot" napona. U prvom delu rada su prikazani rezultati eksperimentalnih ispitivanja, dok su u drugom delu predstavljeni rezultati numerički analiza i određivanja klase otpornosti na zamor primenom tri pomenuta pristupka.

Ključne reči: Čelični mostovi, sanacija šavova, napon zamora, zamor zavarenih spojeva, procena zamora 